\title{
Implication of satellite images in studying potential hydrocarbon resources in the licence Blocks 9 and 11, the exclusive economic zones of Egypt and Cyprus
}

\author{
(C) O.M. Rusakov ${ }^{1}$, I. N. Korchagin ${ }^{1}$, N.A. Yakymchuk ${ }^{2,3}$, S.P. Levashov ${ }^{2,3}$, \\ V.D. Soloviev ${ }^{1}$, D. N. Bozhezha ${ }^{3}, 2018$ \\ ${ }^{1}$ Subbotin Institute of Geophysics, National Academy of Sciences of Ukraine, \\ Kiev, Ukraine \\ ${ }^{2}$ Institute of Applied Ecology, Geophysics and Geochemistry, Kiev, Ukraine \\ ${ }^{3}$ Management and Marketing Center of Institute of Geological Sciences, \\ National Academy of Sciences of Ukraine, Kiev, Ukraine
}

Received 30 November 2017

\begin{abstract}
Використано частотно-резонансну технологію для обробки і декодування супутникових знімків ліцензійних блоків 9 і 11 у Східному Середземномор'ї. У досліджуваному районі виявлено аномалії типу "нафта і газ". Супергігантське газове родовище Зохр зумовлює чітку аномалію площею $251 \mathrm{kм}^{2}$. Цій аномалії відповідає наявність каналів вертикальної міграції глибоких вуглеводневих флюїдів і горизонтальний градієнт пластового тиску в резервуарі родовища. Вперше запропоновано використовувати ці дві характерні особливості як індикатори рентабельності перспективної структури. На їх основі для розвідувального буріння було рекомендовано кілька аномалій типу "нафта і газ" у блоках 9 і 11. Наявна інформація не дає змоги розглядати перспективну структуру Онісіфор як рентабельне газове родовище. Силіцикластична і карбонатна моделі розвідувальних робіт однаковою мірою ефективні у єгипетській, кіпрській та ізраїльській ексклюзивних економічних зонах. У них абіогенний метан є основним компонентом газу, що піднімається до пасток з глибших шарів. Вибір оптимального місцеположення буріння потребує міжАисциплінарного підходу.
\end{abstract}

Ключові слова: конус виносу Нілу, басейн Левіант, декодування супутникових знімків, класифікація перспективних структур, походження вуглеводнів.

Introduction. The Eastern Mediterranean is one of the world's most attractive areas for hydrocarbons exploration due to numerous gas fields and discoveries (Fig. 1) and an acceptable rate of drilling success [Gardosh, 2016]. The USGS estimated technically recoverable gas reserves at about 6.2 and 4.0 trillion cubic meters (TCM) in the Nile Delta Basin Province and Levant Basin Province, respectively [Kirschbaum et al., 2010; Schenk et al., 2010]. The total reser- ves of 10.2 TCM are enough to supply the worldwide consumption for about 2.5 years at a mean rate of expenditure in 2014-2016 [BP Statistical ..., 2017].

Based on the results from the Abu Madi, El Temsah, Ha'py, Roseta, Roven, Atoll (Egyptian EEZ), Tamar, Leviathan, Dalit, Dolphin, Noa, Tanin, Pinnacles and Karish (Israeli EEZ) gas fields, exploration targeted Oligocene-Pliocene siliciclastic plays in the EEZs. The biggest Egyptian Atoll field con- 


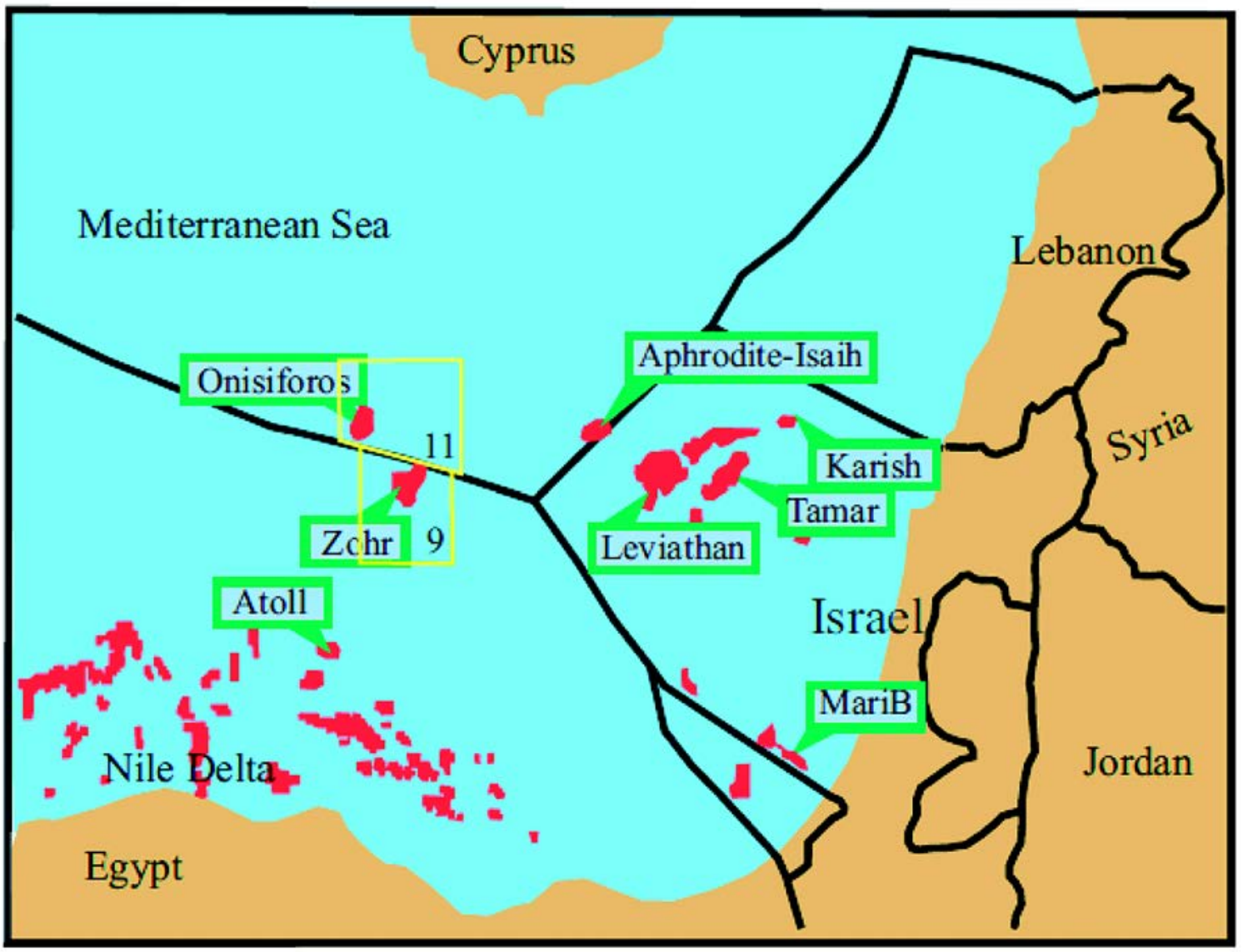

Fig. 1. Location of the hydrocarbon fields and discoveries of the Egyptian, Israeli and Cypriot EEZs in the Eastern Mediterranean [Kirschbaum et al., 2010; Esestime et al., 2016]. 9 and 11 are numbers of the Blocks 9 and 11.

tains 42 billion cubic meters (BCM) of gas and 4.3 billion metric tons (BMT) of condensate [Atoll ..., 2016].

In 2015 the supergiant Zohr gas field was discovered whose probable reserves are 845
BCM. As gas is concentrated in the Early to Middle Miocene coral reefs at the base of the thick carbonate platform in the Egyptian EEZ, the exploration programmes of this field discoverer were increasingly shifted

T a b l e 1. Major gas fields in the siliciclastic reservoirs [Ellinas et al., 2016; Atoll ..., 2016]

\begin{tabular}{|c|c|c|c|}
\hline Fields & $\begin{array}{c}\text { Probable } \\
\text { reserves (BCM, } \\
\text { BMT) }\end{array}$ & Discovery date & Status \\
\hline Aphrodite (gas) & 128 & 2011 & Pursuing gas sales \\
Tamar (gas) & 280 & 2009 & Producing \\
Leviathan (gas) & 620 & 2010 & Pursuing gas sales \\
Zohr (gas) & 845 & 2015 & Pursuing gas sales \\
Atoll (gas) & 42 & 2015 & Start of production, 2018 \\
(condensate) & 4.3 & & \\
\hline
\end{tabular}


towards searching for large limestone build-ups in the Levantine platform in the area south of Cyprus where the Miocene paleolagoons are widespread. After intensive seismic campaign an inference was made that in the Cypriot EEZ there's a similar to the Zohr type hypergigantic reserve which is estimated as, at least 5 times, greater than Zohr [Conophagos et al., 2016]. Consequently, the carbonate build-up was drilled by Onisiforos W-1 well in the B11, just near the Zohr field. Drilling the well was completed (September, 2017) with the shocking results [Paraskova, 2017]. The Onisiforos gas field is not commercially viable because its reserves are ca.14 BCM that is 60 times less than in the Zohr field. Nevertheless, Cypriot Energy Minister Giorgos Lakkotrypis considers the results encouraging because they confirm the working of the geological model of Zohr that makes it possible to continue exploration activity in the frame of this concept. However, the only way to minimize exploration risk is to include direct methods of hydrocarbon prospecting into multidisciplinary geological-geophysical works.

The aim of this investigation is to perform the case study from the Zohr field (Egyptian EEZ) with use of the frequency-resonance technology (FRT) for processing and decoding the satellite images and to apply results to recommend sites for exploration drilling in the Blocks 9 (B9) and 11 (B11) of the Eastern Mediterranean Sea.

Material and method. The geological sketch of the Zohr field was based on the interpretation of the seismic line (Fig. 2, $a, b$ ). The field is the biggest in the Eastern Mediter-
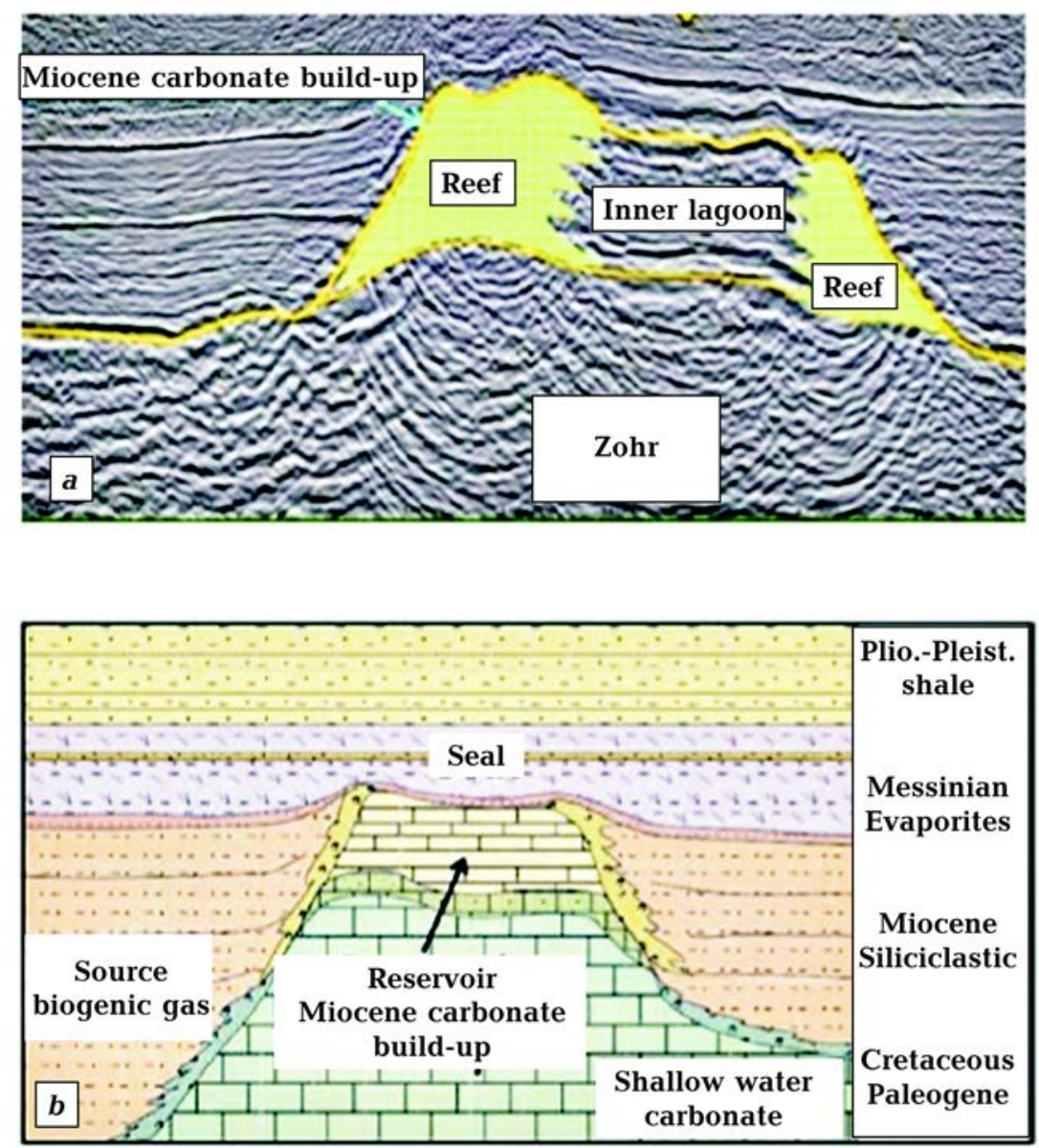

Fig. 2. Seismic line across the Zohr gas field $(a)$ and its geological sketch $(b)$ [Esestime, 2016; Gardosh, 2016]. 
ranean. It is situated at a water depth of $1450 \mathrm{~m}$ near Egyptian-Cypriot limit of the EEZs [Esestime et al., 2016]. The exploration well was drilled to $4131 \mathrm{~m}$. The structure occupies $100 \mathrm{~km}^{2}$ with the thickness of gross gas column of $628 \mathrm{~m}$. The gas recoverable reserves are $845 \mathrm{BCM}$. The field reservoir is a porous carbonate built-up of the Early to Middle Miocene age at the base of a thick sequence of Messinian evaporites within the Levantine Platform. Gas is suggested to be biogenic migrated from Cenozoic source rocks, which are sealed by the Messinian Evaporitic complex.

The propriety FRT is used for processing and decoding the satellite images of the B9 and B11. Its various aspects are described in a number of publications, including [Levashov et al., 2011, 2012, 2017 a]. Here are only the basic principles for the concept of direct hydrocarbon search and exploration to get a clear idea of it without addressing other sources.

The novel technology is based on the generally accepted fact that each kind of molecules has own strict resonance frequencies of electromagnetic field radiation [Hedvig, 1975]. The frequency of any matter is governed by the chemical composition and molecular structure or spatial lattice of material. This phenomenon is tested by experiments in laboratory. One of the numerous examples is presented in Table 2.

An accumulation of homogenous material creates a characteristic frequency of electromagnetic radiation whose intensity is proportional to the amount of material. At the
Earth's surface the modulated signals of a characteristic frequency contain proper information on the structure, quantity and composition of the material which after discriminating can be used to uniquely identify matter of interest. The carrier signals are modulated by low frequency electromagnetic and seismo-magnetic signals of the lithospheric origin including those from hydrocarbon fields [Shuman, 2007]. A technique of determining reservoir pressure was developed by experiments on the known hydrocarbon fields. A new terminology was introduced to classify the results of remote sensing: the anomalous zones of "gas deposit", "oil reservoir", "gas-condensate accumulation" and "oil and gas occurrence" types. It's worth mentioning that these zones themselves don't necessarily indicate commercial hydrocarbon accumulation.

For frequency-resonance processing the multispectral images are used from different satellites which are in the public domain. The images of Landsat 5 and Landsat 7 with a resolution of $30 \mathrm{~m} /$ pixel are used to performing reconnaissance surveys of large areas and to processing data on a scale of 1 : 50000 and smaller. In looking for small objects the data should be processed on a larger scale and high-resolution images of $2.5-1.0 \mathrm{~m} /$ pixel are needed. The processing time for a satellite image in the A3 format is $2-3$ days.

Frequency-resonance processing and decoding satellite images are based on a special algorithm for pattern recognition. A laser beam is divided into two absolutely iden-

T a b le 2. Resonance frequencies for water of different mineralization [Levashov et al., 2017 b]

\begin{tabular}{|c|c|c|}
\hline Water types & $\begin{array}{c}\text { Mineralization, } \\
\mathrm{g} \cdot \mathrm{dm}^{-3}\end{array}$ & $\begin{array}{c}\text { Resonance } \\
\text { frequencies, } \mathrm{kHz}\end{array}$ \\
\hline Structured from Alpine sources & $<1$ & 717.6 \\
Weakly mineralized from Morshynski sources & $0.1-0.4$ & 643.8 \\
Average mineralization & $0.5-1.0$ & 615.7 \\
Strong mineralization & $5.0-15.0$ & 551.5 \\
\hline
\end{tabular}


tical beams by an optical divider. The first beam is modulated by the signal of hydrocarbons experimentally registered over oil and gas fields while the second one is focused on the satellite image of the study area. A special processor compares these images to discriminate a signal of sufficiently increased intensity due to a resonance effect that indicates the presence of hydrocarbons.

The ability of technology to searching for hydrocarbons was proved by a combined study of ground and satellite methods on the hydrocarbon fields in Ukraine (Shebelinske, Subbotinske, Kobzovske), Kazakhstan (Tengiz, Kazhigali, Teren-Uzuyk, Koshkimbet, Karaton) and Turkmenistan (Douletabad-Donmez, Yuzhnyi Iolotan). The estimation of relative pressure of fluids in reservoirs is principal advantage over available remote sensing techniques due to sufficient increase in the ability to select places for commercially successful drilling.

Results. The FRT revealed 3 vast anomalous zones of the "oil and gas" type in the B9 in the Egyptian EEZ and B11 in the Cypriot EEZ [Levashov et al., 2015]. The anomaly-1 (A-1), A-2, A-3 occupies 105, 104, $42 \mathrm{~km}^{2}$ respectively (Fig. 2). The total area of all the anomalous zones is $251 \mathrm{~km}^{2}$. Tectonic faults are delineated in area of the Zohr field.

The contour of the A-1 (Fig. 3) corresponds exactly to that of the larger reef (Fig. 4) of the Zohr build-up mapped by the 3D seismic survey [Goliat ..., 2015]. Within the A-1 three pressure intervals are determined. The first oil and gas-saturated horizon is characterized by a change in reservoir pressure from 37.2 to $41.8 \mathrm{MPa}$. Taking into account the hydrostatic principle, this pressure corresponds to a depth of $3720-4180 \mathrm{~m}$. The estimated thickness of the productive horizon is $460 \mathrm{~m}$. In the second hydrocarbon horizon reservoir pressure varies from 50.7 to $56.2 \mathrm{MPa}$ at a depth of $5070-5620 \mathrm{~m}$. In the third horizon, the pressure ranges in the interval of $65.0-65.7 \mathrm{MPa}$, between 6500 and $6570 \mathrm{~m}$. The depths of the gas-bearing

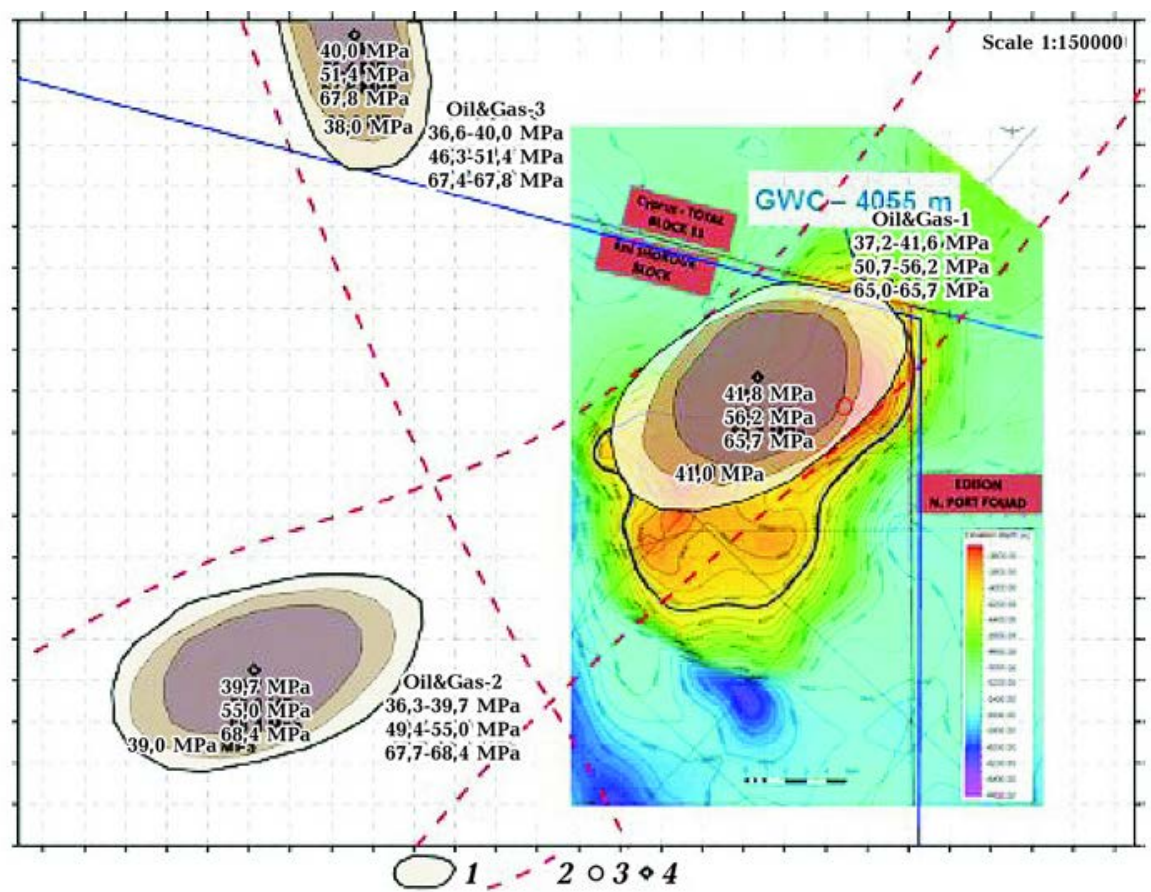

Fig. 3. Location of the anomalous zones of "oil and gas" type in the area of the Zohr field: 1 - contour of the anomalous zones; $2-$ tectonic faults; 3 - position of the Zohr-1 well; 4 - vertical zones of fluids migration from the FRT data. GWC - gas-water contact. 


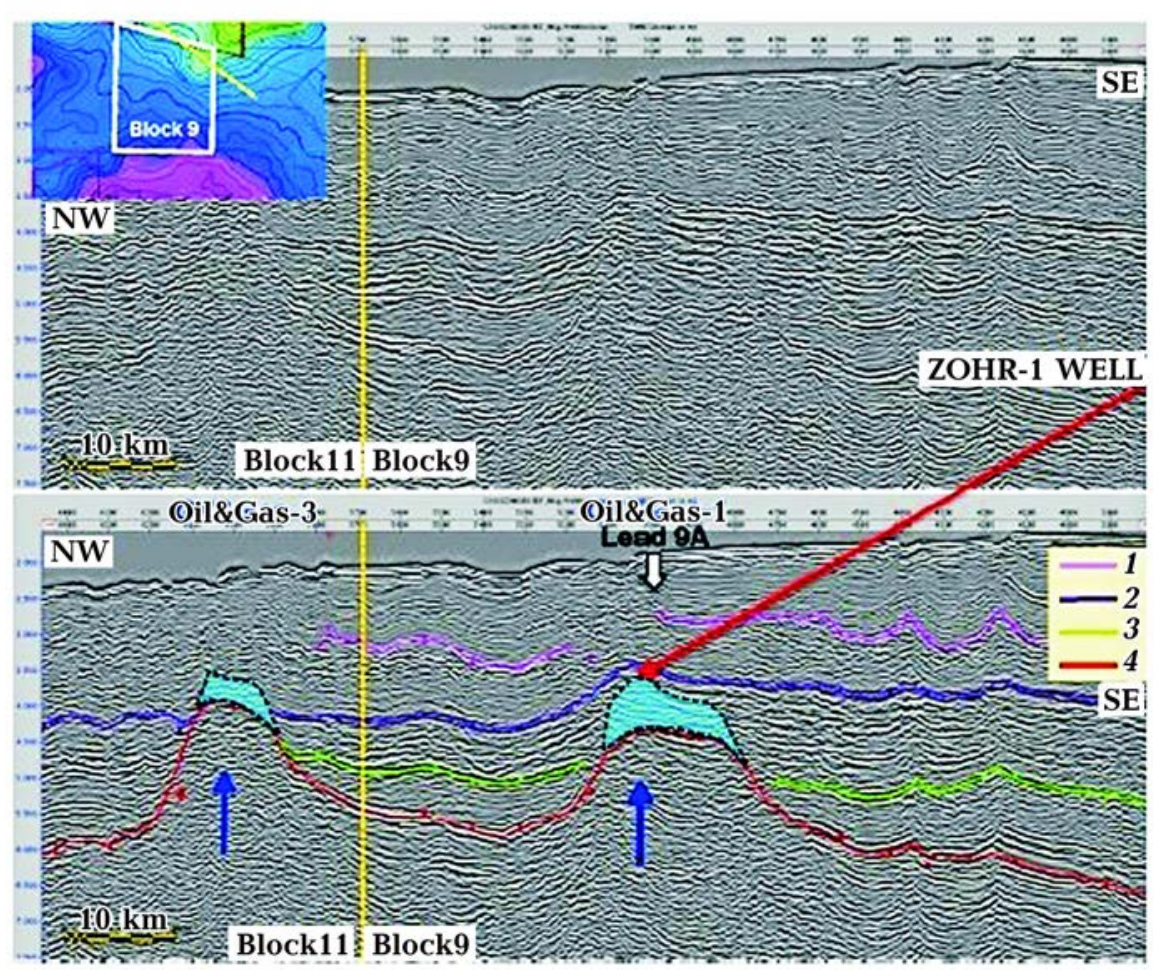

Fig. 4. Comparison of the results from the FRT and 3D seismic surveys in the B9 and B11 [Goliat ..., 2015]. Blue arrows indicate vertical zones of fluids migration from the FRT data.

horizons are in good agreement with the drilling data [Goliat ..., 2015]. The second example of the impressive coincidence from independent methods is presented in Fig. 4 where the A-1 and A-3 fully coincide with the anticline structures on the seismic crosssections. However, the results of the FRT are more informative than of this survey because they revealed the zones of vertical fluids migration and anomalous reservoir pressure. The increase in the reservoir pressure toward the vertical migration zone is the common phenomenon of 14 hydrocarbon fields studied by the FRT all over the world [Levashov et al., 2015]. The role of these observations in the hydrocarbon accumulation will be discussed further.

Three anomalous zones of the "oil and gas" type of different areas were found in the southwestern B9 (Fig. 5). Only the A-1 is an object of interest due to its parameters. The area of the A-1 along the contour of zero pressure is $25.5 \mathrm{~km}^{2}$ decreasing to
$13.3 \mathrm{~km}^{2}$ along the isoline of $60 \mathrm{MPa}$. A thickness of the gas-bearing horizons is estimated to be 50,100, 540 and $260 \mathrm{~m}$. The maximum value of fluids pressure is $141 \mathrm{MPa}$. A narrow vertical channel of deep fluids migration is traced in the center of anomaly.

After extensive 2/3D seismic campaign well Kg-70-1 was drilled by Shell in 2007, which did not provide compelling evidence to continue exploration. If we take into account the results of the FRT only such an outcome is possible as the well is located outside the anomalous zone.

Fig. 6 presents results of the FRT in the B11 nearby the Egyptian EEZ. The configuration of the "oil and gas" A-1 is the same as that of seismically derived. It is located at a distance of only $5 \mathrm{~km}$ from the base of the Zohr field. Along the isoline of zero pressure the area is $46 \mathrm{~km}^{2}$ and along the pressure contour of $60 \mathrm{MPa}$ it is $10.5 \mathrm{~km}^{2}$. Three intervals of reservoir pressure are estimated at a depth of $120 \mathrm{~m}, 510 \mathrm{~m}$ and $40 \mathrm{~m}$. 
The maximum value of fluids pressure is $141 \mathrm{MPa}$. There is a small local vertical conduit of deep fluids migration near the center of the A-1.
After failure drilling by the Onisiforos West-1 well in the Block 11, the detailed FRT was applied on 18-22 August, 2017 [Levashov et al., $2017 \mathrm{c}$ ]. It turned out that the

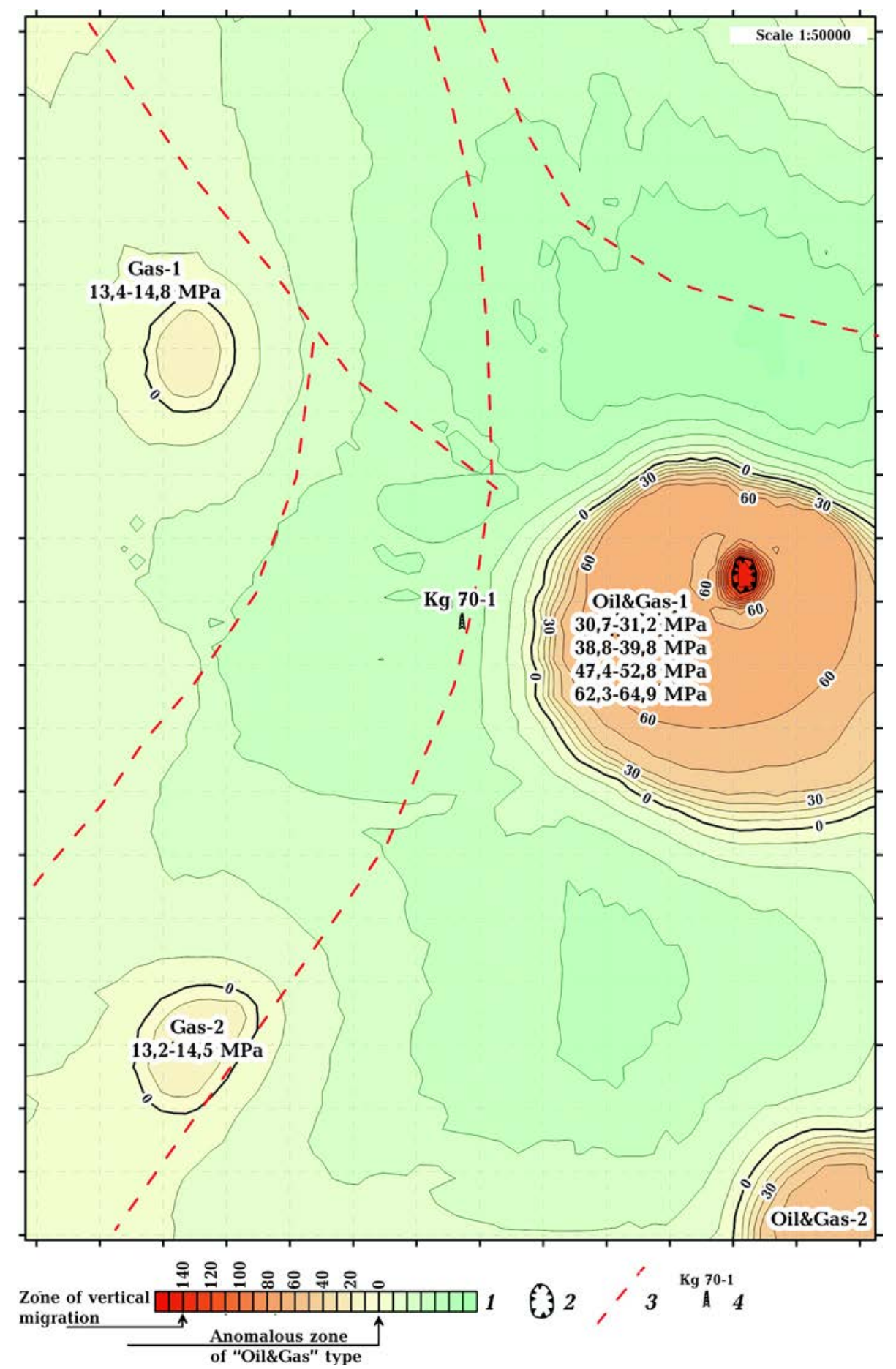

Fig. 5. Location of the anomalous zones of "oil and gas" type in the area of the $\mathrm{Kg}-1$ well [Levashov et al., 2015]: 1 - scale of the values of reservoir pressure, MPa; 2 - location of the vertical channel of fluids; 3 - tectonic faults; 4 - position of the Kg-1 well. 


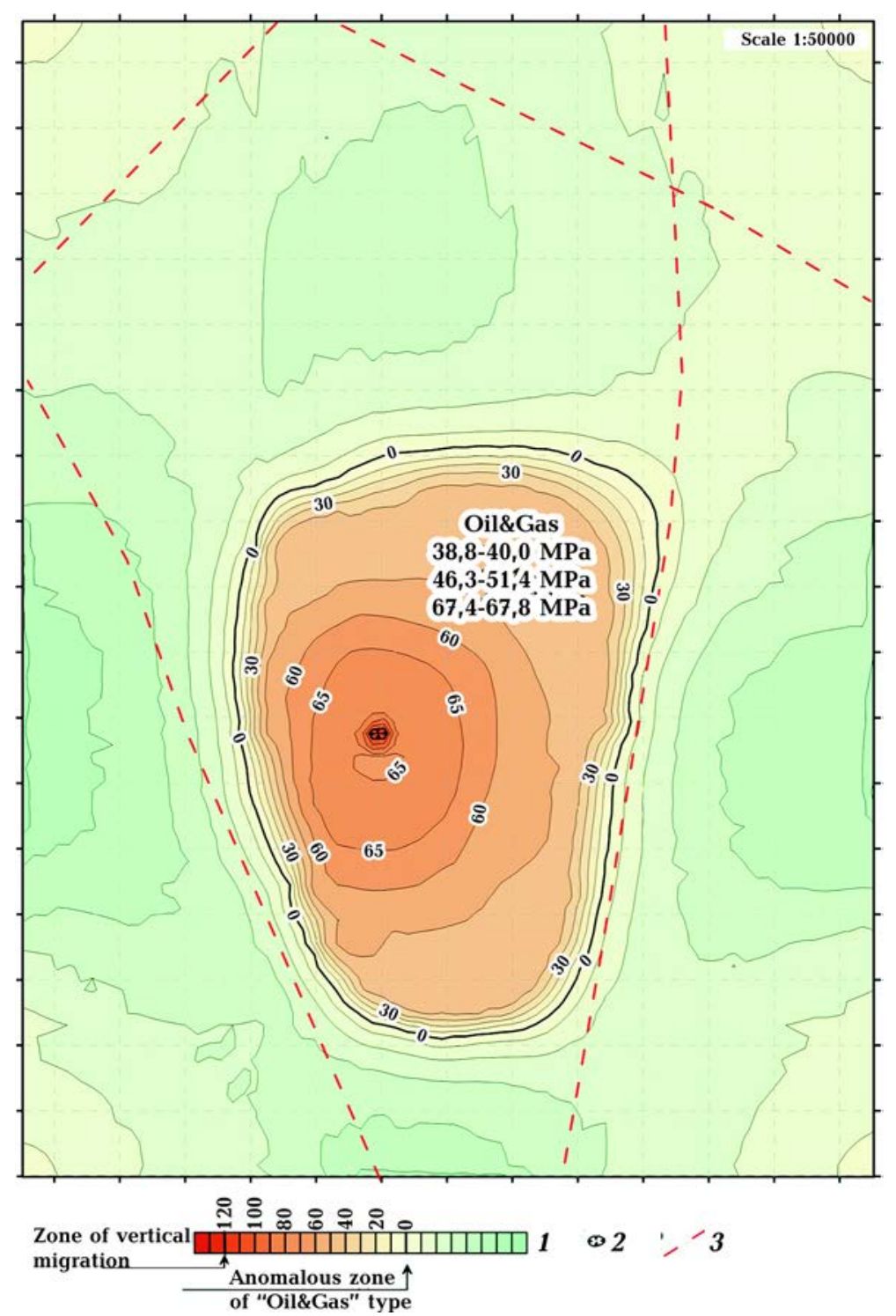

Fig. 6. Location of the anomalous zone of "oil and gas" type in the B11 of the Cypriot EEZ nearby the Zohr gas field [Levashov et al., 2015]: 1 - scale of the values of reservoir pressure, MPa; 2 - location of the vertical channel of fluids; 3 - tectonic faults.

well was located at the southeastern end of the distinct "gas" type A-1 (Fig. 7). The anomalous zone along the zero MPa isoline has $42 \mathrm{~km}^{2}$, along the $50 \mathrm{MPa}$ isoline is $29 \mathrm{~km}^{2}$. The maximum value of reservoir pressure is $53.5 \mathrm{MPa}$. To the north of the well within the A-1 the channel was revealed for vertical migration of deep fluids.

Discussion and conclusions. Based on full support for the results of the FRT by those of 3D seismic profiling and Zohr-1 well, an attempt is made to analyze a hydrocarbon play (conceptual model) for planning exploration activity in the B9 and B11. The hydrocarbon origin, area of anomalous zones, amount of reservoir pressure and occurrence of fluids channels and tectonic faults are used as inseparable indicators for a commercial discovery.

There are exploited four distinct petroleum plays of ages from the Triassic to Pliocene in the Eastern Mediterranean Region [Es- 
sestime et al., 2016]. They are inferred from the notions of source rocks, reservoirs, seals and generation-migration of hydrocarbons. The Zohr play is widely considered as the most profitable because it is able to be characteristic of the whole Egyptian and Cypriot EEZs. Its major elements are biogenic gas, source rocks of the Oligocene and Miocene age and top seal of the from thick Messinian Evaporites. However, this approach should be treated with caution due to the complete failure results from the Onisiforos West-1 well [Paraskova, 2017]. In the frame of the Zohr play this fiasco is absolutely unexplainable. The constituents of the Zohr play are common for the carbonate platform at least in the B9 and B11 while the Onisiforos West-1 well is spudded at a distance of only $5 \mathrm{~km}$ from the base of the Zohr field.

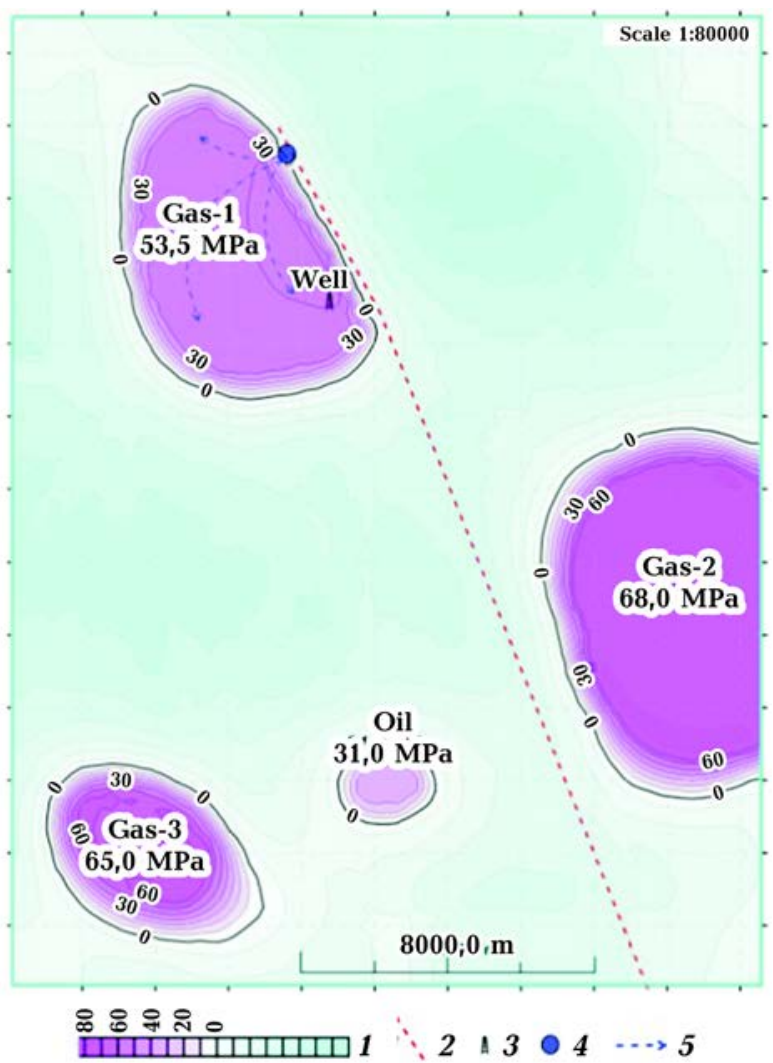

Fig. 7. Location of the anomalous zones of "gas" type in the area of the Onisiforos West-1 well: 1 - scale of the values of reservoir pressure, $\mathrm{MPa} ; 2$ - tectonic fault; 3 - location of the Onisiforos West-1 well; 4 vertical channel of gas migration; 5 - gas migration paths of vertical migration of deep fluids.
The vaguest component of the most popular siliciclastic and carbonate plays of the Eastern Mediterranean is the origin of gas due to the absence of appropriate information on gas composition from big hydrocarbon fields in public domain. The Italian Company ENI determined the gas origin of the Zohr field by analogy with its previous identification case for the giant "Perla" biogenic gas field, Venezuela [Conofagos, Fokianou, 2017]. The Zohr field was created in a karstified limestone reservoir at the margin of paleo-lagoon in the Miocene similarly to the paleogeographic setting of the Perla field. The discovery of the Zohr field is considered as a significant breakthrough in the exploration strategy. Due to the ENI model the exploration efforts should be focused on seismically localizing karstified build-ups in the carbonate platform of the Eastern Mediterranean.

In all hydrocarbon plays the gas origin is inferred from type of source sediments revealed by seismic interpretations in the Eastern Mediterranean (see for example [Peck, Horscroft, 2005; Lie, Trayfoot, 2009; Di Cuia, 2017]). Such an approach defines, a priori, the gas origin as biogenic. The same conclusion is reached from thermogenic petroleum systems of deep horizons because they deal with thermally matured organic matter in sediments [Marlow, 2014]. The only mention on the deep gas composition came from the Leviathan Well-1 [Petzet, 2012]. A gas-bearing zone at about $590 \mathrm{~m}$ depth contains gas heavier that in the well's shallower intervals suggesting it's a thermogenic source.

This factual observation is in line with a regional geochemical study of 38 gas samples from the nine wells drilled the western Nile Fan. They approximate location (Fig. 8) is only given due to a proprietary request [Vandré et al., 2007]. The samples of the Early Miocene to Pliocene age range in depth from $1527-4480 \mathrm{~m}$. To increase validity of geochemical data information from other sampling sites is also used from the eastern Nile Fan and Israeli offshore.

The values of $\delta^{13}$ and $C_{1} /\left(C_{2}+C_{3}\right)$ for methane vary from -66 to $-40 \%$ and 15 


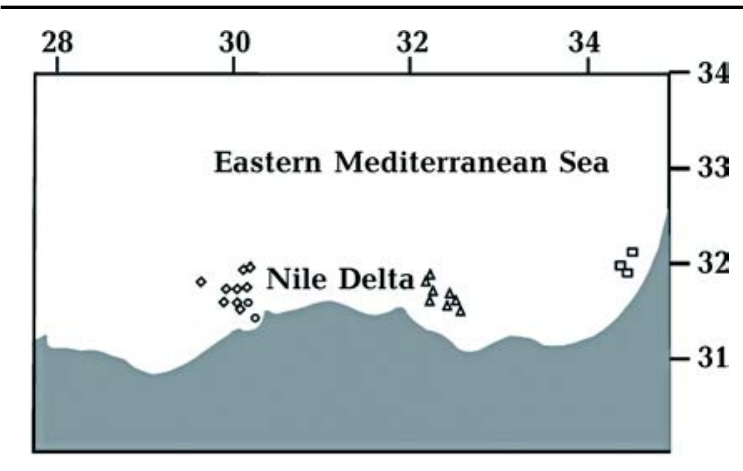

Fig. 8. Locations of sampling sites for the regional geochemical study [Vandré et al., 2007].

to 2000, respectively. They are presented in the form of the Bernard and Whiticar plots to identify the gas origin because it is widely used approach (Fig. 9, $a, b$ ). The values indicate microbial (2000-66 \%o) and thermogenic (13-35\%) origins for the most of the samples. However, the gas wetness index and in- $\mathrm{C}_{4}$ ratios don't change with depth undoubtedly indicating that methane either has resulted from microbial altering thermogenic hydrocarbons in situ or from migrating thermogenic gas upwards from a greater depth. The highest level of biodegradation is determined in the Pliocene reservoir shallower than $2400 \mathrm{~m}$. In turn, the values of $\delta^{13}$ between $-66.0 \%$ and $-39.6 \%$ and $\delta \mathrm{D}$ from $-183 \%$ o to $-148 \%$ o classify methane as a mixture of the thermogenic and microbial origin.

Only gas of the thermogenic origin is characteristic of the Miocene reservoirs. Microbial methane is determined in the Pliocene to recent sediments. The older sediments accumulated gas that moved upwards from greater depths. The intermediate gas composition results from coexistence of the end members of these gases.

Minor contribution of the biological methane into the dominant gas pathways was registered in practically the same areas in the offshore of the Nile delta [Younes, 2015]. This result is supported by a low content of organic carbon $(0.15-1.15 \%)$ in the bottom deposits and the Upper Miocene, Pliocene and Pleistocene sediments $(<0.3 \%)$ in the Eastern Mediterranean [Kendric et al.,
1978; Pedrosa-Pámies et al., 2015]. Good source rocks are considered to have $2-5 \%$ of total organic content [Dolson, 2016].

A geochemical analysis of 20 samples was made from the Miocene and Plio-Pleistocene reservoirs of the Abu Qir, N. Abu Qir, Temsah, Wakkar and port Fouad fields (Fig. 10) [Younes, 2015]. The natural gas contains $96.2-99.37 \%$ of methane. The stable carbon and hydrogen isotopic composition of methane varies from -65.6 to $-40.3 \%$ o PDB and from - 140 to $-170 \%$ o VPDB strongly indicating mixture of thermogenic and early microbial methane (Fig. 11). Only thermogenic methane is found in gas from the western province. Type III kerogen from terrestrial organic material is determined whose maturity parameter $\left(\mathrm{R}_{0}\right)$ ranges from $0.6-$ $0.5 \%$. As kerogen is cracked into thermal gas at $1.05 \mathrm{R}_{0}$ [Norman, 2014] the thermal gas from the Miocene sediments in the study area has abiogenic origin. Furthermore, in the Levant Basin and surrounding continental margins the Mesozoic sediments were mainly deposited in deep water [Esestime et al., 2016]. The pelagic sedimentation resulted in deep water detrial limestones, chalks, marls and shale. Siliciclastic were locally deposed due to a change in drainage of nearby land. Only the Triassic sediments are composed of shallow water carbonates, local evaporites and minor siliciclastics. Therefore, terrestrial material is not a source of Type III kerogen to be cracked into thermogenic gas. From this follows that thermogenic gas is of abiogenic origin in the Mesozoic sediments of the Eastern Mediterranean.

A model of generating two types of methane is presented in Fig. 12 [Al-Balushi et al., 2016]. The PT conditions are believed to be favourable for the large accumulation of biogenic gas just below the Messinian evaporites and for thermogenic gas in the Cretaceous deposits from which it leaks vertically to the Cenozoic reservoirs. The comparison between Figs. 9, $b$ and 11 demonstrates their full identity.

As basin and petroleum systems modelling is a standard procedure in the exploration activity [see, for example, the comp- 
rehensive book of [Hantshel, Kauerauf, 2009], it has been most successfully applied to elucidate the formation and transformation of hydrocarbon in the Eastern Mediterranean by [Halstenberg, 2014] and [Al-Balushi et al., 2016]. The paleo-temperatures calibrated for the Tamar and SPO-1 wells allow us to evaluate their role in these processes us- ing new experimental information on biochemical processes.

The stable carbon and hydrogen isotopic composition of methane was analyzed from the Isis and North Alex mud volcano on the western Nile deep-sea fan, about $55 \mathrm{~km}$ from Alexandria [Mastalerz et al., 2007]. As the values of $\delta^{13} \mathrm{C}$ and $\delta \mathrm{D}$ are $55.1 \%$ o
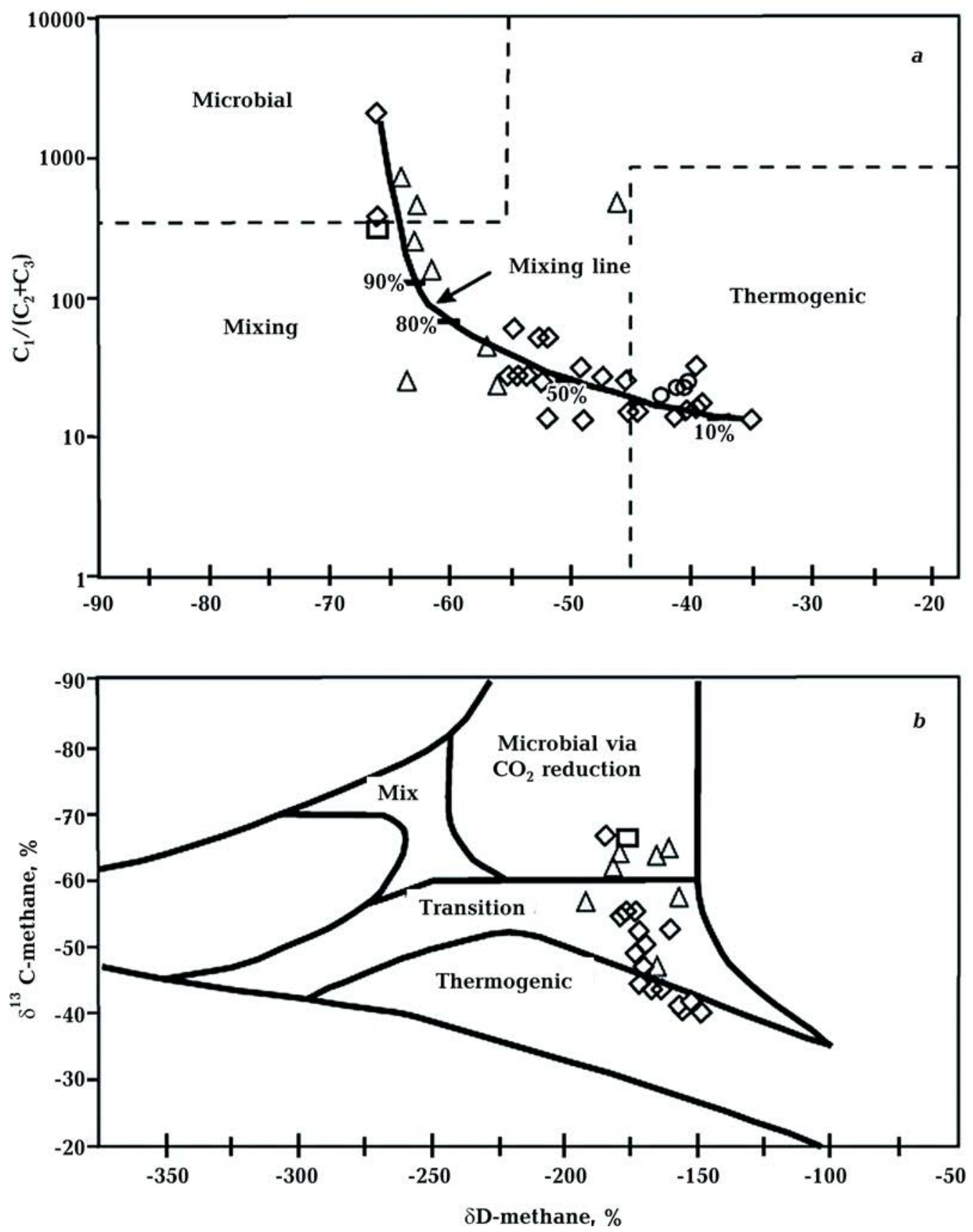

Fig. 9. Diagrams of carbon $\left(\delta^{13}\right)$ vs. $\mathrm{C}_{1} /\left(\mathrm{C}_{2}+\mathrm{C}_{3}\right)(a)$ and carbon $\left(\delta^{13}\right)$ vs. hydrogen $(\delta \mathrm{D})(b)$ for methane from the wells of the Egyptian and Israeli coast [Vandré et al., 2007]. 


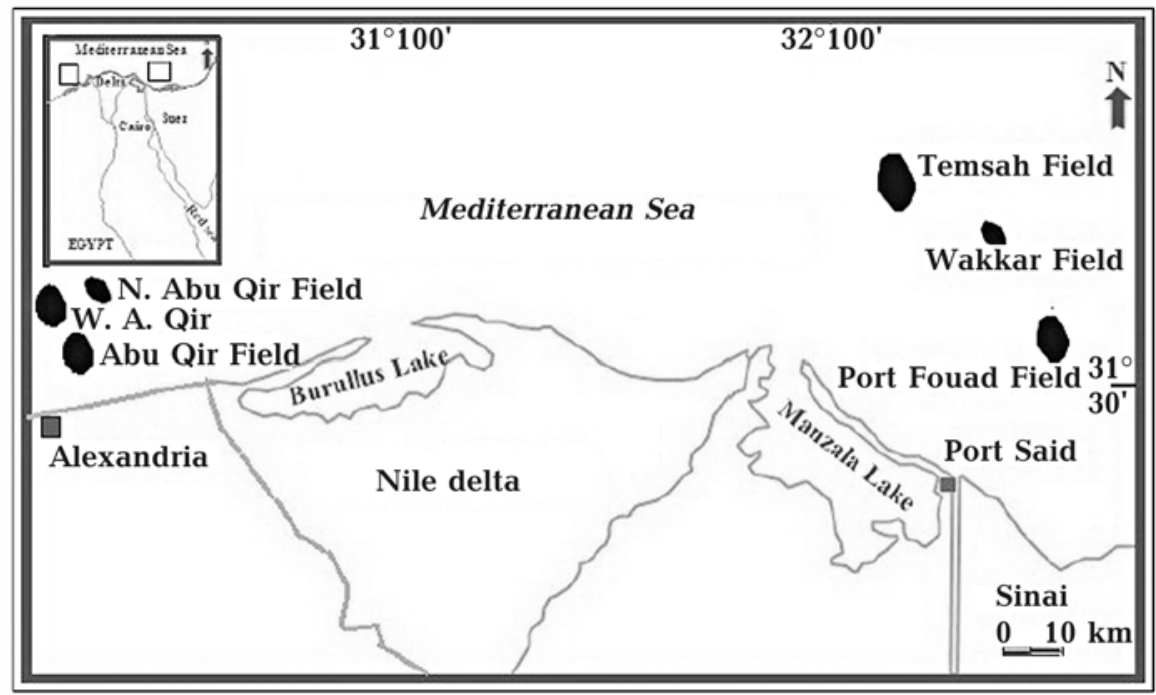

Fig. 10. Locations of sampling gas field for regional geochemical analysis

[Younes, 2015].

VPDB and $203 \%$ \% VSMOW, respectively the methane origin is mainly thermogenic. Ascending fluids from deeper horizons are also revealed.

A new "clumped isotopic" technique revealed that the temperature for the formation of biological gas is less than $50^{\circ} \mathrm{C}$ and that for thermogenic gas ranges from 155 to $221^{\circ} \mathrm{C}$ [Stolper et al., 2014]. These results strongly support the above inference of the original thermogenic gas in the Miocene sediments of Egyptian, Israeli and Cypriot EEZs as to the temperature at their top was $60-$ $70{ }^{\circ} \mathrm{C}$ [Halstenberg, 2014; AlBalushi et al., 2016]. On the other hand, an archaeal consortium which is considered to be the major anaerobic methanogen of the sea environment cannot produce biomethane in the Mesozoic sediments for further cracking into thermogenic gas. The reason is that the

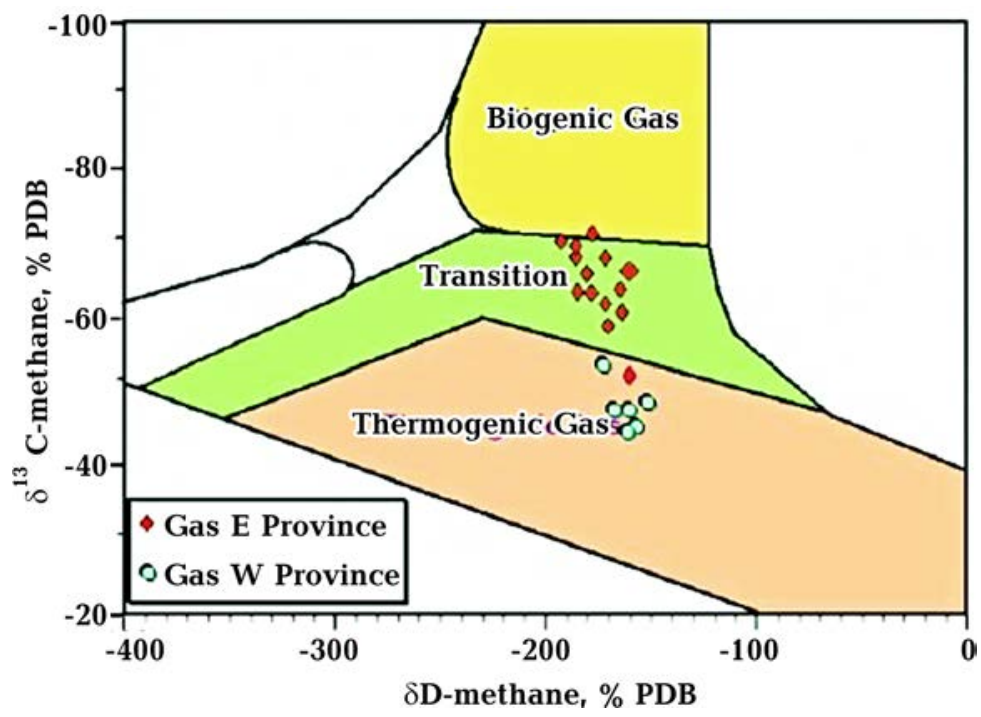

Fig. 11. Diagram of carbon $\left(\delta^{13}\right)$ vs. hydrogen $(\delta D)$ for methane from the Nile Delta [Younes, 2015]. 
temperature at their top $\left(120^{\circ} \mathrm{C}\right)$ is higher than the upper limit for Archaea life which is $121^{\circ} \mathrm{C}$ [Kashefi, Lovley, 2003]. In other words, the thermogenic gas of abiogenic origin is predominant in the Miocene and deeper sediments off the Egyptian and Israeli coast.

Foregoing information leads to a logical conclusion that hydrocarbon plays based on only multichannel seismic-reflection profile data and on the biological hydrocarbon concept are not successful in planning the most economical exploring for prospective oil and gas discoveries. For example, Shell acquired $1862 \mathrm{~km}$ of 2D seismic lines, $7183 \mathrm{~km}^{2}$ of 3D seismic data and drilled 9 failure exploration wells in B9 before new concessioner Eni discovered the Zohr field, having performed additional seismic surveys during 3 years. From this follows that drilling success rate is only $10 \%$. Selecting wells places resulted in a very poor achievement similar to that of the old-time "wild cat" approach which was exploited in unstudied areas without any preliminary works. In this context, it is interesting inside story of ar- riving at the ENI mega achievement: "Like all great exploration discoveries also the Zohr discovery is full of surprises, the unexpected, intuitions, mistakes, skill, enthusiasm, and ups and downs in which the human element is as crucial as the technology ..., fortune favours the brave, right? Right. If Eni had not decided to bring forward the exploration of Zohr, we would not be here talking about it" [Alfieri, 2015]. As such, their decisions appear largely to have been based on emotions rather than on an objective analysis of the available options from relevant multimethod data to obtain the best result.

To explain such a situation a comparative analysis was made between the FRT results from the Zohr and Onisiforos gas fields. With regard to seismic data, they demonstrate similar geological setting of these fields that was the basis for an optimistic forecast to discover new reserves 5 times greater than the Zohr [Conophagos et al., 2016]. The difference between the FRT results from the Zohr and Onisiforos gas fields is conceptual due to the absence of the gradient

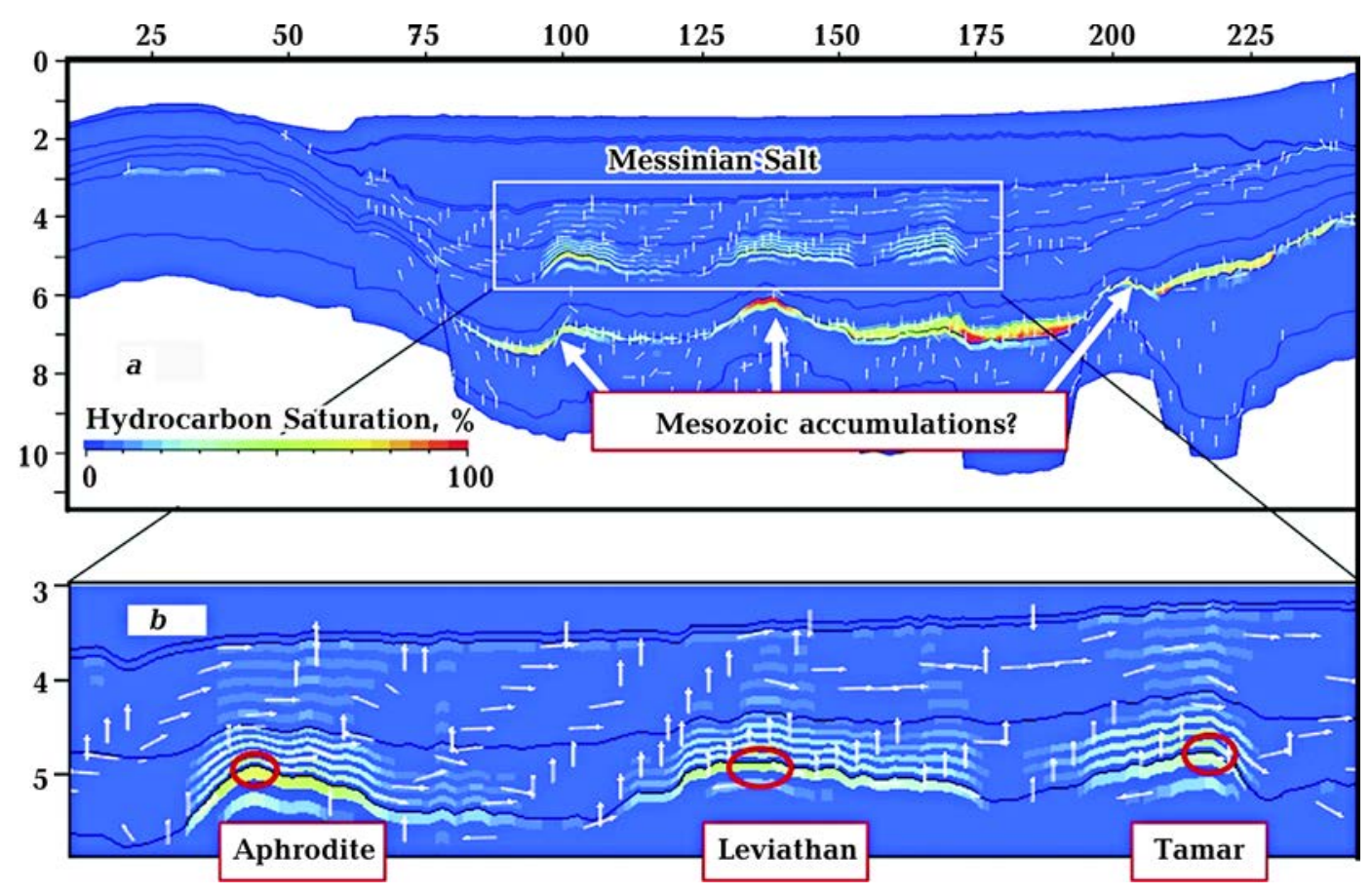

Fig. 12. Model for the origin of biogenic and thermogenic hydrocarbons in the Aphrodite, Leviathan and Tamar gas-oil fields [Al-Balushi et al., 2016]. 
of reservoir pressure in the Onisiforos discovery (See Fig. 6) that is proved to be an integral feature of commercial hydrocarbon fields [Levashov et al., 2017a].

There exists co-occurrence of exclusive commercial and non-commercial wells within the same big hydrocarbon field [Bembel et al., 2003]. This phenomenon can be exemplified by the Em-Egovskoe field in the West Siberian oil basin (Russia). Here nine wells were drilled in the area of $1 \mathrm{~km}^{2}$. However, during 10 years $92 \%$ of oil was extracted from only the well $\mathrm{R}-2$ while the rest oil recovery was provided by eight wells. The reason for extremely large productivity of the well R-2 is that it was accidentally drilled near the vertical channel of abiogenic fluids, which is characterized by high pressure ("geosoliton tube"). This is particularly the case for the situation of the Zohr and Onisiforos wells when the latter was penetrated the reservoir in a site of the background pressure.

Therefore, the fluid mechanism is the most suitable for origin fields in the B9 and B11 because the methane is mainly thermo- genic in the major gas field of the Eastern Mediterranean (see the previous text) and the Zohr Well-1 is located near the vertical channel of high pressure (See Fig. 3). Another line of evidence in favour of this mechanism comes from the interpretation of the magnetic survey in the area of the hydrocarbon fields in the Eastern Mediterranean [Petrova, Petrishchev, 2011].

To the west of the Nile Delta and near the southern coast of the Cyprus gas fields are confined to the inclined zone of decreased magnetization at a $20-4 \mathrm{~km}$ depth (Fig. 13,a). The similar zone occurs beneath the Nile Delta and the Tamar gas field (Fig. 13,b). The Dalit gas field is confined to the low magnetization lens (2-4 km depth) above the zone of the same condition at a depth of $10-12 \mathrm{~km}$ (Fig. 13, c). The magnetization decrease results from hydrocarbon reworking due to influence of upwelling flows of heated material from the mantle along weaken tube-like zones in the lithosphere. There is a network of intraplate (mantle) tectonic faults delineated by multi-geophysical approach in the area of gas fields of the Ni-
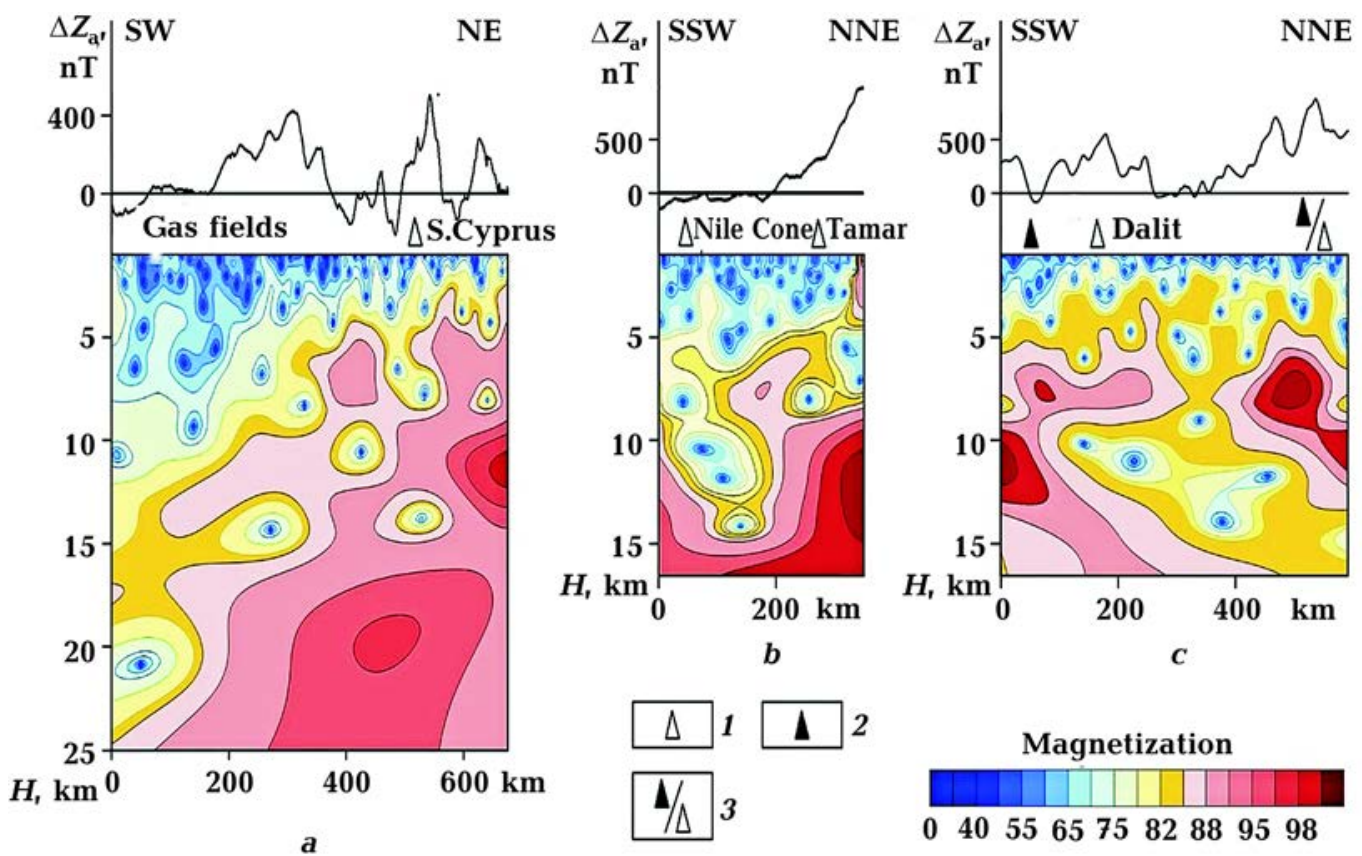

Fig. 13. Geomagnetic cross-sections of the gas fields in the Eastern Mediterranean [Petrova, Petrishchev, 2011]. Fields: 1 - gas; 2 - oil; 3 - supposed zones of oil and gas accumulation. 
le Delta and Levantine Basin [Eppelbaum, Katz, 2011]. They are able to provide favourable conditions for forming such pathways. Thus, selecting an optimal drilling location should be based on integrated studies.

Based on the concept of migration of abiogenic hydrocarbon together with deep fluids along vertical conduit and the increase in the reservoir pressure toward this pathway (the peculiarities of the Zohr gas field), producible volume of hydrocarbons is prognosed within the areas of the B9 and B11 "oil and gas" type anomalies (See Figs. 5, 6). Available information evidences for non-commercial gas accumulation in the Oniciforos discovery.

In concussion, the major results are as follows.

1. The anomalies of "oil and gas" type were revealed by the frequency-resonance technology of processing and decoding the satellite images of the licence B9 and B11.

2. Most of them evidence for the vertical pathways for migration of deep fluids and the horizontal gradient of the reservoir pressure.

3. As these features are characteristic of the anomaly from the Zohr gas field they are first used as the indicators of a commercial discovery.

4. Based on these indicators the optimal locations are recommended for exploration drilling in the B9 and B11. The Onisiforos discovery can't be considered as commercial.

5. In the Miocene sediments, abiogenic gas is mostly determined by available information on the stable carbon and hydrogen isotopic composition of methane from the wells and paleotemperature regime off the Egyptian and Israeli coast.

6. The siliciclastic and carbonate plays are equally useful for planning exploration activity in the B9 and B11. To decrease the in potential risk of drilling requires an interdisciplinary approach.

\title{
Implication of satellite images in studying potential hydrocarbon resources in the licence Blocks 9 and 11, the exclusive economic zones of Egypt and Cyprus
}

\author{
(C) O. M. Rusakov, I. N. Korchagin, N.A. Yakymchuk, S.P. Levashov, \\ V.D. Soloviev, D. N. Bozhezha, 2018
}

\begin{abstract}
A frequency-resonance technology was used for processing and decoding the satellite images of the licence Blocks 9 and 11 in the Eastern Mediterranean. The anomalies of "oil and gas" type were revealed in the study area. The supergiant Zohr gas field produces the prominent anomaly covering the largest area of $251 \mathrm{~km}^{2}$. This anomaly evidences for the channels for vertical migration of deep hydrocarbon-bearing fluids and the horizontal gradient in reservoir pressure. For the first time, these two specific findings were suggested to be indicators of a commercial discovery. Based on them, several "oil and gas" type anomalies were recommended for exploration drilling in the Blocks 9 and 11. Available information cannot allow us to consider the Onisiforos discovery as a commercial gas field. The siliciclastic and carbonate plays are equally workable in the Egyptian, Cypriot and Israeli EEZs where in the Miocene sediments abiogenic methane is the main component of gas which ascends to reservoirs from deeper layers. Selecting an optimal drilling location requires an interdisciplinary approach.
\end{abstract}

Key words: Nile Fan, Levant Basin, satellite images decoding, discoveries classification, hydrocarbons origin. 


\section{References}

Atoll Gas Field, North Damietta Offshore Concession, East Nile Delta. www.offshore-technology. com/.../atoll-gas-field-north-damietta-offshore-concession-... 30 June 2016.

Al-Balushi A., Neumaier M., Fraser A., Jackson $C ., 2016$. The impact of the Messinian Salinity Crisis on the petroleum system of the Eastern Mediterranean: a critical assessment using 2D-petroleum system modelling. Petroleum Geoscience 22, 357-379. https://doi. org/10.1144/petgeo2016-054.

Alfieri M., 2015. The discovery and development of the Zohr gas field in Egypt | Eniday. https: //www.eniday.com/en/human_en/discovery-development-gas-zohr.

Bembel R. M., Megeria V.M., Bembel S. R., 2003. Geosolitons: the functional system of the Earth, conception, exploration and exploitation of hydrocarbon fields. Tyumen, Vector Buk, 224 p. (in Russian).

BP Statistical Review of World Energy, June 2017. https://www.bp.com/.../bp/.../energy.../statistical-review-2017/bp-statistical-review-of-wo.

Conophagos E., Lygeros N., Foskolos A., 2016. Target reserve 5 times greater than ZOHR within the Cypriot EEZ. https://www.cyprusgas news.com/target-reserve-5times-quater-Zohr/.

Conofagos E., Fokianou T., 2017. "Zohr" Supergiant Biogenic Gas Field Discovery \& Its Importance for Greece. www.academia.edu/.../ _Zohr_Supergiant_Biogenic_Cas_Discovery.

Di Cuia R., 2017. East Mediterranean: the new frontier opens. http://www.researchgate.net/ ...316109903_EAST_MEDITERRANAEN THE_NEW_ $\overline{\mathrm{F}}$.

Dolson J., 2016. Understanding Oil and Gas Shows and Seals in the Search for Hydrocarbons. Cham, Switzerland: Springer Int. Publ., $486 \mathrm{p}$.

Ellinas C., Roberts J., Tzimitras H., 2016. Hydrocarbon developments in the Eastern Mediterranean. Washington DC Atlantic Council. http://www.atlanticcouncil.org/publications/ reports/hydrocarbon-developments-in-theeastern-mediterranean.

Eppelbaum L., Katz Y., 2011. Tectonic-Geophysical Mapping of Israel and the Eastern Mediterranean: Implications for Hydrocarbon Prospecting. Positioning 2(1), 36-54. doi: 10. 4236/pos.2011.21004.
Erestime P., Hewitt A., Hodgson N., 2016. Zohr - a newborn carbonate play in the Levantine Basin, East-Mediterranean. First Break 34, $87-93$.

Gardosh M., 2016. The Levant Basin - A WorldClass Hydrocarbon Province in the SE Mediterranean Sea. http://www.energy-sea.gov.il/ English-Site/PublishingImages/Pages/Forms /EditForm/RoadshowPresentationDr.Michael Gardosh_LevantBasinHCPotential.pdf.

Goliat Field Trip, 2015. https://www.eni.com/ docs/it IT/enipedia/informazioni.../2015/ goliat-final-website.

Hanstelberg D. B., 2014. Reconstruction of Tectonic Paleo-Heat Flow for the Levantine Basin (Eastern Mediterranean). Implications for Basin and Petroleum System Modelling. Master of Science Thesis, RWTH Aachen University, Aachen, Germany. 84 p.

Hantshel T., Kauerauf A., 2009. Fundamentals of Basin and Petroleum Systems Modeling. Berlin, Heidelberg: Springer Verlag, 476 p.

Hedvig P., 1975. Experimental Quantum Chemistry. New York - London: Academic Press, $534 \mathrm{p}$.

Kashefi K., Lovley D. R., 2003. Extending the upper temperature for life. Science 301 (5635), 934. doi: 10.1126/science.1086823.

Kendrick J.W., Hood A., Castano J.R., 1978. Petroleum-generating potential of sediments from the Eastern Mediterranean and Black Sea. Initial Reports of the Deep Sea Drilling Project. Vol. XLII Part 2, Washington (U.S. Government Printing Office), 729-735.

Kirschbaum M.A., Schenk C.J., Charpentier R.R., Klett T. R., Brownfield M.E., Pitman J.K., Cook T.A., Tennyson M.E., 2010. Assessment of undiscovered oil and gas resources of the Nile Delta Province, Eastern Mediterranean. U.S. Geological Survey Fact Sheet FS 2010-3027. 4 p. http:// energy.cr.usgs.gov/oilgas/.

Levashov S.P., Yakymchuk N.A., Korchagin I.N., 2011. Assessment of relative value of the reservoir pressure of fluids: results of the experiments and prospects of practical applications. Geoinformatika 2, $19-35$ (in Russian).

Levashov S.P., Yakymchuk N.A., Korchagin I.N., 2012. Frequency-resonance principle, mobile geoelectric technology: a new paradigm of Geophysical Investigation. Geofizicheskiy zhurnal 34 (4), 167-176 (in Russian). 
Levashov S. P., Yakymchuk N.A., Korchagin I.N., Bozhezha D. N., 2015. Operative assessment of hydrocarbon potential of Zohr prospect in the Mediterranean Sea (Shorouk block, Egypt offshore) by the frequency-resonance method of the remote sensing data processing and interpretation. doi: 10.13140/RG.2.1.2917.9360.

Levashov S. P., Yakymchuk N.A., Korchagin I.N. et al., 2017 a. Application of mobile and direct-prospecting technology of remote sensing data frequency-resonance processing for the vertical channels of deep fluids migration detection. NCGT Journal 5(1), 48-91.

Levashov S., Yakymchuk N., Korchagin I., 2017 b. On the Possibility of Using Mobile and Direct-Prospecting Geophysical Technologies to Assess the Prospects of Oil-Gas Content in Deep Horizons. In: Oil and Gas Exploration: Methods and Application. Eds S. Gaci, O. Hachay. American Geophysical Union. P. 209-236.

Levashov S.P., Yakymchuk N.A., Korchagin I.N., Bozhezha D. N., 2017 c. Preliminary results of the oil and gas potential estimation in area of "Onisiforos West-1" Well drilling in Mediterranean Sea (block 11 on the Cyprus offshore). Geology of seas and oceans. Proc. of XXII Int. Conf. on Marine Geology, Moscow, November 20-24, 2017. Vol. II, P. 201-205.

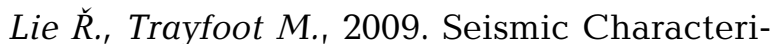
zation of the First 3D Surveys Offshore Cyprus and Lebanon. Search and Discovery Article \# 10194. http://www.searchanddiscovery.com/pdfz/documents/2009/10194lie/images/lie.pdf.html.

Mastalerz V., de Lange G.-J., Dählmann A., Feseker T., 2007. Active venting at the Isis mud volcano, offshore Egypt: Origin and migration of hydrocarbons. Chemical Geology 246 (12), 87-106. https://doi.org/10.1016/j.chemgeo.2007.09.005.

Marlow L., 2014. Tectonostratigraphic History and Petroleum Potential of the Levantine Basin, Eastern Mediterranean. AAPG Memoir 106: Petroleum Systems of the Tethyan Region. P. $279-299$.

Norman J.H., 2014. Dictionary of petroleum exploration, drilling \& production. Tulsa: Pen Well corporation, $769 \mathrm{p}$.

Paraskova T., 2017. Onisiphoros gas field not commercially viable. http://oilprice.com/Latest-Energy-News/World-News/New-GasDiscovery-Offshore-Cyprus-Not-Commercially-Viable.html.
Peck J. M., Horscroft P., 2005. "Bottom-up" analysis identifies eastern Mediterranean Prospects. www.offshore-mag.com/.../lsquobottom-uprsquo-analysis-identifies-eastern-mediterra.

Pedrosa-Pàmies, R., Parinos C., Sanchez-Vidal A., Gogou A., Calafat A., Canals M., Bouloubassi I., Lampadariou N., 2015. Composition and sources of sedimentary organic matter in the deep eastern Mediterranean Sea. Biogeosciences 12, 7379-7402. https://doi.org/10.5194/ bg-12-7379-2015.

Petrova A.A., Petrishchev M.S., 2011. Fluid systems of the Mediterranean. Vestnik KRAUNTS. Nauki o Zemle 17 (1), 23-33 (in Russian).

Petzet A., 2012. Noble halts Leviathan deepening in gas formation. Oil \& Gas Journal. http://www.ogi.com/articles/2012/05/noblehalts-leviathan-deepening-in-gas-formation. html.

Schenk C.J., Kirschbaum M.A., Charpentier R.R., Klett T.R., Brownfield M.E., Pitman J.K., Cook T.A., Tennyson M.E., 2010. Assessment of Undiscovered Oil and Gas Resources of the Levant Basin Province, Eastern Mediterranean, U. S. Geological Survey Fact Sheet, 20103014, 4 p.

Shuman V.N., 2007. Electromagnetic signals of the lithospheric origin in the modern ground and remote sensing. Geofizicheskiy zhurnal 29 (1), 42-48 (In Russian).

Stolper D.A., Lawson M., Davis C.L. et al., 2014. Formation temperatures of thermogenic and biogenic methane. Science 6191:1500-1503. Technical Report. 2012. Block 9, Shorouk offshore. www.egas.com.eg/BidRound2012/ block009.pdf.

Technical Report. Block-9 Shorouk offshore EGAS. www.egas.com.eg/BidRound2012/block 009.pdf 2012.

Vandré C., Cramer B., Gerling P., Winsemann J., 2007. Natural gas formation in the western Nile Delta (Eastern Mediterranean): thermogenic versus microbial mechanisms. Org Geochem 38(4), 523-539. https://doi.org/10.1016/ j.orggeochem.2006.12.006.

Younes M.A.-A., 2015. Natural Gas Geochemistry in the Offshore Nile Delta, Egypt. In: Advances in Petrochemicals, P. 27-40. http:// dx.doi.org/10.5772/60575. 